\title{
DIFFUSING THE IMPACT \\ OF TOKENISM ON \\ FACULTY OF COLOR
}

Yolanda Flores Niemann, Utah State University

In addition to the expected challenges related to teaching, research, service, and the tenure and promotion process, faculty of color often experience the impact of token status, or tokenism. This chapter describes the personal, psychological, and career-damaging impacts of tokenism and provides guidelines for professional development professionals that may diffuse these negative impacts by assisting department heads to mentor faculty of color.

University faculty face similar experiences and challenges related to teaching, research, service, and the tenure and promotion process. In addition to these expected challenges, faculty of color are vulnerable to token status, or tokenism. Tokenism occurs, in part, when those in the numerical minority account for 15 percent or less of the total workforce in a given context (Kanter, 1977; Mullen, 1991; Niemann, 2003; Niemann \& Dovidio, 1998a). More than numerical status, a critical but insufficient identifier of tokenism, tokenized contexts impose negative personal, psychological, and career-damaging effects on faculty of color (Gutierrez y muhs, Niemann, Gonzales, \& Harris, in press). Symptoms of tokenized contexts include the collective and damaging effects of isolation and loneliness, visibility and distinctiveness, representativeness and role encapsulation, stereotype threat, and attributional ambiguity (Niemann, 1999, 2003; Niemann \& Dovidio, 1998a). These impacts are especially pervasive in predominantly white institutions that lack a numerical critical mass of faculty of color, and they are exacerbated in predominantly white communities (Niemann \& Dovidio, 1998a).

Faculty development professionals can help minimize the roots of tokenism and negative experiences associated with tokenized contexts 
for faculty of color. They can intercede to diffuse symptoms of tokenism, primarily through their influence on department head training. Department heads are the main lifeline for faculty as their primary administrator, advocate, and professional development mentor, but their lack of training belies this critical role. Most department heads assume their roles without the skills or experience needed to mentor faculty of color. Faculty development professionals' understanding of the university context, along with their skills and experience in effecting change in that context, makes them critical players in training department heads to mentor of faculty of color.

\section{Isolation, Loneliness, and Alienation}

Faculty of color in token contexts may experience isolation, loneliness, and alienation (Johnsrud, 1993; Niemann, 1999, 2003; Niemann \& Dovidio, 1998a; Washington \& Harvey, 1989). Universities and their departments may be oppressive without conscious maliciousness and subject people of color to subtle and overt experiences of racism (Niemann, 2003; Niemann \& Dovidio, 1998a). In tokenized contexts, the burdens of institutional and individual racism weigh heavily, but the psychological safety associated with numbers is not available to persons who work in these isolated situations (Washington \& Harvey, 1989). Faculty of color often do not have opportunities to form relationships with persons who understand the impacts of being a member of a minority group that is subjected to intentional or unintentional discrimination and "isms."

Tokens report feelings of isolation that result in part from pressures to assimilate and doubts from their majority group counterparts regarding their competency (Fontaine \& Greenlee, 1993). They spend time and cognitive energy ruminating about these experiences and their responses, or lack of responses, to the situation (Lord \& Saenz, 1985; Niemann, 1999; Saenz \& Lord, 1989; Steele, 1997, 2010). The more that tokens ruminate about experiences or events not directly related to their work, the more stressed and isolated they become, which begins a vicious circle (Ellsworth, 1993; Niemann, 2003).

Tokens are culturally isolated. In predominantly white institutions, the cultural values and mores may be very different from those of communities of color. Tokens must attempt to acclimate and, in some cases, assimilate to fit in with the predominant culture. Often as a result, they experience symptoms of loneliness, isolation, alienation, and burnout 
that include intense cynicism, seeing life activities as valueless, pressure to dissociate themselves from others, and arrogance (Machell, 1988-1989).

\section{Distinctiveness}

Due to their low numbers, tokens work in situations that make them particularly distinctive and visible (Cota \& Dion, 1986; Fiske \& Taylor, 1991; Kanter, 1977; McGuire, McGuire, Child, \& Fujioka, 1978; Niemann, 1999, 2003, in press; Niemann \& Dovidio, 1998a; Pollak \& Niemann, 1998). Their novelty within groups often makes tokens feel as if they are in a glass house (Kanter, 1977; Niemann, 2003, in press; Niemann \& Dovidio, 1998a), and they attract disproportional attention and causality (Taylor \& Fiske, 1976), or responsibility for outcomes. That is, because tokens are so visible, their words and behaviors are easier to recall than are those of more homogeneous group members. This attention is reflected in group members' general, but not specific, recollection of the group experience. Consequently when things go well, token group members receive some credit, but when outcomes are not good, they receive much of the blame (Taylor \& Fiske, 1976). For instance, when only one person of color is part of a committee discussion, that person's statements will be the ones most recalled. If a committee's outcomes are positive, the person of color will be praised; when the outcomes are negative, the person of color will be blamed, even when his or her statements or actions are ancillary to the decisions or outcomes (Mullen, 1991; Taylor \& Fiske, 1978).

The distinctiveness that tokens describe is largely negative. It is not the type of distinctiveness felt by a Nobel Prize winner or high-ranking officer of the university (Niemann, 2003). Tokens' salience creates psychological discomfort and places them on constant guard about the implications of their words, behaviors, and very presence. They feel a stressful sense of having no privacy or freedom to be themselves. This distinctiveness becomes uncomfortable to the extent that tokens report fearing visibility (Kanter, 1977; Niemann, in press).

The distinctiveness of tokens results in exaggeration of differences between faculty of color and their white colleagues (Fiske \& Taylor, 1991). Tokens must often pretend that racial differences do not exist or have no implications (Niemann, 1999). Their white colleagues will often assert that they are "color-blind," not realizing that such comments are considered insulting by their very denial of tokens' identity and experiences in the institution (Niemann, 2005). At times, tokens 
may don a "white mask" to fit in with white colleagues (AlexanderSnow \& Johnson, 1999). Distinctiveness and visibility are so uncomfortable that faculty of color often forgo their cultural selves when they are in their faculty roles and portray the cultural behaviors and preferences of their white colleagues in an effort to blend in with the racial or ethnic majority.

Consistent with feelings of distinctiveness, tokens often believe that they are evaluated under different, and more stringent, criteria than their white colleagues are. Their actions and words are heavily scrutinized. Faculty of color report increased pressure to outperform others and to outshine and outthink their colleagues (Fontaine \& Greenlee, 1993). Everything they do and say, from their attire, to their choice of music, to their opinions on political or controversial matters, to their latest research project, will become public knowledge quickly. In contrast, typical faculty within the same department generally do not know the research topics of their white colleagues.

Due to their distinctive salience and the added stress induced by these situations, tokens may engage in self-monitoring (Snyder, 1979) and defensive impression management strategies to establish particular attributes in the eyes of others (Tedeschi \& Norman, 1985). Tokens' self-protective attributions exacerbate a state of cognitive busyness (Crocker \& Major, 1989), resulting in more memory and problem-solving deficits than nontokens have (Lord \& Saenz, 1985; Salvatore \& Shelton, 2007; Schmader, Forbes, Zhang, \& Mendes, 2009), which may have an impact on their job performance. These deficits are interpreted to be a function of their cognitive busyness with their minority status rather than with any inherent personal deficits (Lord \& Saenz, 1985). That is, simultaneously managing their distinctiveness and the task at hand strains tokens' cognitive resources.

Tokens' individuality seems nonexistent as their racial, ethnic, group, or social identity becomes increasingly salient. As tokens become preoccupied with issues pertaining to self-distinctiveness and self-presentation strategies, they feel less satisfied with their jobs (Niemann \& Dovidio, 1998a).

\section{Representativeness, Stereotyping, and Role Encapsulation}

As the size of the minority group decreases relative to the majority, tokens not only become perceived as increasingly distinctive from the majority, they are perceived as homogeneous (Mullen, 1991), which fuels their stereotyping and role encapsulation. Stereotypes are "pictures 
in our heads" (Lippmann, 1922) that contain a structured set of beliefs, including perceivers' organized knowledge, beliefs, and expectancies about some human group (Fiske $\&$ Taylor, 1991). Because of stereotypical attributions, tokens may be type-cast as specialists in ethnic matters rather than being perceived as qualified in their particular disciplines (Kanter, 1977; Niemann, 1999; Spangler, Gordon, \& Pipkin, 1978). This stereotypical perception leads to tokens' placement in limited and caricatured roles, such as "diversity" committees, or committees where a "person of color voice" is considered beneficial. Tokens report feeling as if they are in special mascot-like roles (Gutierrez y muhs et al., in press; Niemann, in press). They are often deliberately thrust into the limelight as the institution's representative when it is in the interest of the institution to demonstrate a belief in diversity (Kanter, 1977; Niemann, 1999).

Tokens are perceived as symbolic representatives of their ethnic or racial groups (Kanter, 1977; Pollak \& Niemann, 1998). They serve as symbols of their group when they fumble and as unusual examples of their kinds when they succeed (Fiske \& Taylor, 1991; Kanter, 1977; Kunda, 2000). The pressure and stress from this representativeness may be constant, as tokens are often asked to provide a point of view representing their ethnic or racial group. There is a general assumption that they know what "their" group wants or thinks. Faculty of color believe that due to colleagues' biases and their situational visibility and representativeness, they are not allowed any missteps. They must hit the ground running to justify their hiring by white colleagues. Any sign that they are less than the perfect hire will justify racist, stereotypical beliefs that people of color are not qualified for the professoriate or for high-ranking positions in academia (Gutierrez y muhs et al., in press; Niemann, in press). Whether or not they wish to be, they are seen as representatives of their distinctive racial or ethnic group in the university environment. Observers assume that their imperfections and mistakes are reflective of their group. Simultaneously, due to the powerful and stigmatizing impact of negative stereotypes, their successes are seen as exceptions to the rule and as anomalies that are not reflective of their group (Pinel, 1999). Tokens must therefore be continually aware of putting their best foot forward so as not to have a negative impact on others' perceptions of members of their demographic groups.

Tokens become representative of government programs such as affirmative action (Niemann \& Dovidio, 1998b). They are presumed to be in the employ of the institution because of affirmative action policy, and not because they are qualified (Crosby \& Clayton, 1990). Tokens may thus 
carry a stigma of incompetence that accompanies the affirmative action label (Heilman, Block, \& Lucas, 1992), in addition to being objects of racial bias. Role stress represented in role encapsulation and representativeness has been linked to feelings of tension, decreased job satisfaction, and employee turnover (Niemann $\&$ Dovidio, 1998a).

\section{Stereotype Threat}

Tokens may experience stereotype threat, defined as the possibility of proving true the stereotypes about one's group (Steele, 2010). For people of color, especially African Americans and Latinos/as, stereotypes related to intelligence and educational achievement are largely negative, thereby exacerbating the damaging impact of tokenism in the academic context (Garza, 1992; Niemann, 2001). Stereotypes and efforts to avoid being seen as representative of their group may lead tokens to operate in a state of reflective expectancy, a psychological state associated with persistent feelings of anxiety, fear of proving the accuracy of negative racial stereotypes, and living in fear of making a mistake. This state inhibits their work and may even stop their progress toward tenure (Niemann, 2003; Niemann \& Dovidio, 1998a; Pollak \& Niemann, 1998; Steele, 1997, 2010).

For women of color in token situations, the intersections of race or ethnicity and gender are particularly pronounced. They are subjected to greater degrees of discrimination than white women and are doubly disadvantaged in their efforts to advance (Fontaine \& Greenlee, 1993). Because women of color tend to be exoticized in predominantly white environments, they are at particular risk for sexual harassment. They may be stereotyped as easy or passive targets who want the attention of white men, while also experiencing sexism from members of their own ethnic or racial groups, especially those from patriarchal communities (McKay, 1988) in which women are traditionally expected to be subordinate to male group members.

Their awareness that others perceive them in a stereotypical manner can have damaging consequences for tokens' interactions and relations with department colleagues and other institutional personnel. It can have an impact on their job performance and hinder the formation of friendships that could alleviate feelings of isolation and loneliness. It can also preclude formations of alliances and relations with potential mentors, and have strong implications for their success of these minority faculty. 


\section{Attributional Ambiguity}

Tokens live in a state of attributional ambiguity, which refers to not knowing the intentions of the feedback or actions toward or against them (Crocker, Voekl, Testa, \& Major, 1991; Niemann, 1999, 2003). They do not know if negative feedback is racist, or if positive feedback is overly kind and patronizing from unconscious racists who do not have the confidence or courage to provide negative feedback to members of underrepresented groups. Not knowing whether feedback from whites is genuine or is related to prejudice makes it difficult for the stigmatized to predict their future outcomes, select tasks of appropriate difficulty, or accurately assess their own skills and abilities (Crocker \& Major, 1989; Dovidio, Gaertner, Niemann, \& Snider, 2001; Niemann, 1999; Niemann \& Dovidio, 1998a).

Attributional ambiguity can stop the progress of people of color. A key component of success for faculty is mentoring that sees them through the institutional ranks. This mentoring includes constructive, critically analytical feedback on their work from majority white colleagues and supervisors. Not to have trusted feedback is to not know how to improve. Attributional ambiguity results in isolation from collaborative work and intellectual and professional stimulation (Hall, 1990).

\section{Guidelines for Faculty Developers and Administrators}

The effects of tokenism are interconnected. So too are the guidelines that can diffuse or minimize these effects. The guidelines that follow may be implemented to minimize situations that create tokenized contexts and create a more positive university climate and job experience for faculty of color:

- At upper institutional levels, facilitate the establishment of social networks and encourage grassroots organizations of faculty of color. The university president or provost can host gatherings of faculty of color at his or her home to provide opportunities for these faculty to get to know one another. These gatherings provide a university-sanctioned means for faculty of color to find cultural communities and share similar experiences and advice from more senior faculty. Relationships formed in these groups facilitate a sense of belonging and retention (Olmedo, 1990).

- Engage faculty in department meetings, committees, teams, and work groups. During department meetings, seek the participation of all faculty. These interactions provide faculty of color an 
opportunity to be known beyond group stereotypes and to form meaningful relationships and friendships.

- Facilitate department, disciplinary, college, and university unity and identity. These collective identities help diffuse racial stereotypes and identification.

- As part of mentoring, include concrete deadlines, goals, and schedules. A specific, impending goal will help keep focus on productivity and away from ruminations that expend time and energy.

- Facilitate the establishment of reading groups for junior faculty. These groups should contain people who will not be involved in any evaluative process for group members. For that reason, people from outside the member's department will be trusted to provide feedback on drafts of research papers and creative works.

- Ask faculty to select formal mentors rather than assigning mentors. Provide enough flexibility to all faculty to change mentors as they form relationships with colleagues or when they establish researchbased alliances.

- Train mentors of faculty of color to understand the unique experiences associated with tokenism.

- Encourage persons in upper-level ranks, such as presidents, provosts, and deans, to mentor faculty of color. Some of the best informal (nonassigned) mentors for faculty of color are high-status members of the institution who are not competing in any way with their mentees.

- Do not assume that faculty of color are prepared to teach about diversity issues or have the interest or qualifications to serve on diversity-related committees and tasks.

- Ensure that white faculty serve on diversity-related committees. Faculty of color should not be the only persons advocating for diversity-related concerns.

- Value teaching social justice issues. Make sure that white faculty, and not just faculty of color, are assigned to teach this curricular content.

- Protect faculty of color from excess service, unwanted summer teaching, and paid and unpaid overload teaching. At the same time, understand that their cultural values will motivate and inspire them to engage in service to the community at large and to individual and student group advising. Consider providing release 
time to ensure equitable time for their attention to their scholarship and teaching. Be forthright about which of their service contributions will be taken into consideration for tenure, promotion, and salary increases.

- Conduct searches with the intention of diversifying the faculty. When conducting searches, do not equate merit with elite institutions; most faculty of color did not achieve their formal education at Ivy League universities. Ensure that committee members understand federal affirmative action policy and the implications of the policy for faculty searches (Persico, 1990). Being intentional about diversifying the faculty will contribute to the university climate for faculty of color and minimize impacts of tokenism. Rarity and scarcity, rather than being an ethnic or racial minority, shape the environment and set the stage for tokenization. In more ethnically balanced groups that include a critical mass of faculty of color, members have freedom to assume nontraditional roles (Rozell \& Vaught, 1988).

- Express a belief in the added value of diversity and affirmative action rather than relaying the message that the policy is being forced upon the unit (Fine, 1992).

- Acknowledge that intersectionality (for example, intersections of gender, race, socioeconomic status, and sexuality) has implications for faculty's perception of the university climate (Bowleg, 2008; Shields, 2008). Understand that women of color are particularly vulnerable to sexual harassment, and act immediately on accusations of harassment.

- Provide opportunities for frank discussion regarding issues of racism and stereotyping. When faculty of color have colleagues with whom to discuss these issues, they will feel less isolated and may spend less time ruminating about the negative token experiences on their own.

- Do not dismiss issues and experiences related to perceived racism, sexism, and stereotyping. Faculty of color have a unique reality based largely on their tokenized status.

- Acknowledge white privilege. Do not pretend to be color-blind. Be color conscious, noting the added value of faculty of color. Be aware of your own white privilege and aversive racism. Consider taking the implicit association test (https://implicit.harvard.edu/ implicit/demo/) and facing your own prejudices and stereotypes. 
- Use your privileged position to combat practices that subordinate others, including inappropriate jokes, demeaning group identities and accomplishments, dismissal of affirmative action policy, and disregarding the accomplishments of certain colleagues. Be aware that all persons unconsciously hold stereotypes until they consciously deconstruct their prejudices (Devine, 1989).

\section{Conclusion}

Tokenism is a psychological state imposed on faculty of color. It is a function of a social-ecological context that faculty of color are typically left on their own to navigate. In some cases, these faculty, especially those new to the academy, may not have the experience or understanding to be conscious of the effects of token status or to understand how to minimize the negative aspects of the situation. The same is true for their white colleagues, who may want faculty of color to succeed, but lack the knowledge to help their colleagues diffuse the damaging ramifications of tokenism. Professional development professionals, working collaboratively with university administrators and department heads, can promote change that affords faculty of color opportunities to succeed and to have a good quality of life in predominantly white academic institutions.

\section{REFERENCES}

Alexander-Snow, M., \& Johnson, B. J. (1999). Perspectives from faculty of color. In R. J. Menges \& Associates, Faculty in new jobs: A guide to settling in, becoming established, and building institutional support (pp. 88-117). San Francisco, CA: Jossey-Bass.

Bowleg, L. (2008). When black + lesbian + woman = black lesbian woman: The methodological challenges of qualitative and quantitative intersectionality research. Sex Roles, 59(5/6), 312-325. doi:10.1007/s11199-008-9400-z

Cota, A. A., \& Dion, K. L. (1986). Salience of gender and sex composition of ad hoc groups: An experimental test of distinctiveness theory. Journal of Personality and Social Psychology, 50(4), 770-776. doi:10.1037/0022-3514.50.4.770

Crocker, J., \& Major, B. (1989). Social stigma and self-esteem: The self-protective properties of stigma. Psychological Review, 96(4), 608-630.

Crocker, J., Voelkl, K., Testa, M., \& Major, B. (1991). Social stigma: The affective consequences of attributional ambiguity. Journal of Personality and Social Psychology, 60(2), 218-228. 
Crosby, F., \& Clayton, S. (1990). Affirmative action and the issue of expectancies. Journal of Social Issues, 46(2), 61-79. doi:10.1111/j.1540-4560.1990 .tb01923.x

Devine, P. G. (1989). Stereotypes and prejudice: Their automatic and controlled components. Journal of Personality and Social Psychology, 56(1), 5-18.

Dovidio, J. F., Gaertner, S. L., Niemann, Y. F., \& Snider, K. (2001). Racial, ethnic, and cultural differences in responding to distinctiveness and discrimination on campus: Stigma and common group identity. Journal of Social Issues, 57(1), 167-188. doi:10.1111/0022-4537.00207

Ellsworth, E. (1993). Claiming the tenured body. In D. Wear (Ed.), The center of the web: Women and solitude (pp. 63-74). Albany: State University of New York Press.

Fine, T. S. (1992). The impact of issue framing on public opinion: Toward affirmative action programs. Social Science Journal, 29(3), 323-334. doi:10.1016/0362-3319(92)90025-D

Fiske, S. T., \& Taylor, S. E. (1991). Social cognition. New York, NY: McGraw-Hill.

Fontaine, D. C., \& Greenlee, S. P. (1993). Black women: Double solos in the workplace. Western Journal of Black Studies, 17(3), 121-125.

Garza, H. (1992). Academic power, discourse, and legitimacy: Minority scholars in US universities. In M. Romero \& C. Candelaria (Eds.), Community empowerment and Chicano scholarship (pp. 35-52). San Jose, CA:

National Association of Chicano Studies.

Gutierrez y muhs, G., Niemann, Y. F., Gonzales, C., \& Harris, A. (Eds.). (in press). Presumed incompetent. Logan: Utah State University Press.

Hall, C.C.I. (1990). Qualified minorities are encouraged to apply: The recruitment of ethnic minority and female psychologists. In G. Stricker, E. DavisRussell, E. Bourg, E. Duran, W. R. Hammond, J. McHolland, . . . B. E. Vaughn (Eds.), Toward ethnic diversification in psychology education and training (pp. 105-111). Washington, DC: American Psychological Association.

Heilman, M. E., Block, C. J., \& Lucas, J. A. (1992). Presumed incompetent? Stigmatization and affirmative action efforts. Journal of Applied Psychology, 77(4), 536-544.

Johnsrud, L. K. (1993). Women and minority faculty experiences: Defining and responding to diverse realities. In J. Gainen \& R. Boice (Eds.), New directions for teaching and learning: No. 53. Building faculty learning communities (pp. 3-16). San Francisco, CA: Jossey-Bass.

Kanter, R. M. (1977). Men and women of the corporation. New York, NY: Basic Books. 
Kunda, Z. (2000). Social cognition: Making sense of people. Cambridge, MA: MIT Press.

Lippmann, W. (1922). Public opinion. New York, NY: Harcourt, Brace. Lord, C. G., \& Saenz, D. S. (1985). Memory deficits and memory surfeits: Differential cognitive consequences of tokenism for tokens and observers. Journal of Personality and Social Psychology, 49(4), 918-926.

Machell, D. F. (1988-1989). A discourse on professorial melancholia. Community Review, 9(1/2), 41-50.

McGuire, W. J., McGuire, C. V., Child, P., \& Fujioka, T. (1978). Salience of ethnicity in the spontaneous self-concept as a function of one's ethnic distinctiveness in the social environment. Journal of Personality and Social Psychology, 36(5), 511-520.

McKay, N. Y. (1988). Minority faculty in [mainstream white] academia. In A. L. Deneef, C. D. Goodwin, \& E. S. McCrate (Eds.), The academic's handbook (pp. 48-64). Durham, NC: Duke University Press.

Mullen, B. (1991). Group composition, salience, and cognitive representations: The phenomenology of being in a group. Journal of Experimental Social Psychology, 27(4), 297-323. doi:10.1016/0022-1031(91)90028-5

Niemann, Y. F. (1999). The making of a token: A case study of stereotype threat, stigma, racism, and tokenism in academe. Frontiers: A Journal of Women Studies, 20(1), 111-135.

Niemann, Y. F. (2001). Stereotypes about Chicanas and Chicanos: Implications for counseling. Counseling Psychologist, 29(1), 55-90. doi:10.1177/0011000001291003

Niemann, Y. F. (2003). The psychology of tokenism: Psychosocial realities of faculty of color. In G. Bernal, J. E. Trimble, A. K. Burlew, \& F. T. Leong (Eds.), The handbook of racial and ethnic minority psychology (pp. 110-118). Thousand Oaks, CA: Sage.

Niemann, Y. F. (2005). Color blindness: Its ironies, impossibilities, and contradictions. In Y. F. Niemann, C. R. Lugo-Lugo, J. Alamillo, L. Guerrero, R. Ong, \& J. Streamas (Eds.), Racial crossroads: A reader in comparative ethric studies (pp. 217-228). Dubuque, IA: Kendall Hunt.

Niemann, Y. F. (in press). Presumed incompetent: Lessons learned from the experiences of race, class, sexuality, gender, and their intersections in the academic world. In G. Gutierrez y muhs, Y. F. Niemann, C. Gonzales, \& A. Harris (Eds.), Presumed incompetent. Logan: Utah State University Press.

Niemann, Y. F., \& Dovidio, J. F. (1998a). Relationship of solo status, academic rank, and perceived distinctiveness to job satisfaction of racial/ethnic minorities. Journal of Applied Psychology, 83(1), 55-71. 
Niemann, Y. F., \& Dovidio, J. (1998b). Tenure, race/ethnicity and attitudes toward affirmative action: A matter of self-interest? Sociological Perspectives, 41(4), 783-796.

Olmedo, E. L. (1990). Minority faculty development: Issues in retention and promotion. In G. Stricker, E. Davis-Russell, E. Bourg, E. Duran, W. R. Hammond, J. McHolland, ... B. E. Vaughn (Eds.), Toward ethric diversification in psychology education and training (pp. 99-104). Washington, DC: American Psychological Association.

Persico, C. F. (1990). Creating an institutional climate that honors diversity. In G. Stricker, E. Davis-Russell, E. Bourg, E. Duran, W. R. Hammond, J. McHolland, ... B. E. Vaughn (Eds.), Toward ethnic diversification in psychology education and training (pp. 55-63). Washington, DC: American Psychological Association.

Pinel, E. C. (1999). Stigma consciousness: The psychological legacy of social stereotypes. Journal of Personality and Social Psychology, 76(1), 114-128.

Pollak, K. I., \& Niemann, Y. F. (1998). Black and white tokens in academia: A difference of chronic versus acute distinctiveness. Journal of Applied Social Psychology, 28(11), 954-972. doi:10.1111/j.1559-1816.1998 .tb01662.x

Rozell, E., \& Vaught, B. C. (1988). The interaction effects of women in groups: A review of the interaction and implications. Arkansas Business and Economic Review, 21(3), 1-15.

Saenz, D. S., \& Lord, C. G. (1989). Reversing roles: A cognitive strategy for undoing memory deficits associated with token status. Journal of Personality and Social Psychology, 56(5), 698-708.

Salvatore, J., \& Shelton, J. N. (2007). Cognitive costs of exposure to racial prejudice. Psychological Science, 18(9), 810-815. doi:10.1111/j.1467-9280.2007.01984.x Schmader, T., Forbes, C. E., Zhang, S., \& Mendes, W. B. (2009, May). A metacognitive perspective on the cognitive deficits experienced in intellectually threatening environments. Personality and Social Psychology Bulletin, 35(5), 584-596. doi:10.1177/0146167208330450

Shields, S. A. (2008). Gender: An intersectionality perspective. Sex Roles, 59(5/6), 301-311. doi:10.1007/s11199-008-9501-8

Snyder, M. (1979). Self-monitoring processes. In L. Berkowitz (Ed.), Advances in experimental social psychology (Vol. 12, pp. 85-125). Orlando, FL: Acadernic Press.

Spangler, E., Gordon, M. A., \& Pipkin, R. M. (1978). Token women: An empirical test of Kanter's hypothesis. American Journal of Sociology, 84(1), 160-170.

Steele, C. M. (1997). A threat in the air: How stereotypes shape intellectual identity and performance. American Psychologist, 52(6), 613-629. 
Steele, C. M. (2010). Whistling Vivaldi: And other clues to how stereotypes affect us. New York, NY: Norton.

Taylor, S. E., \& Fiske, S. T. (1976). The token in a small group: Research findings and theoretical implications. In J. Sweeney (Ed.), Psychology and politics, collected papers (pp. 110-117). New Haven, CT: Yale University Press.

Taylor, S. E., \& Fiske, S. T. (1978). Salience, attention, and attribution: Top of the head phenomena. In L. Berkowitz (Ed.), Advances in experimental and social psychology (Vol. 11, pp. 249-288). Orlando, FL: Academic Press.

Tedeschi, J. T., \& Norman, N. (1985). Social power, self presentation, and the self. In B. R. Schlenker (Ed.), The self and social life (pp. 293-321). New York, NY: McGraw-Hill.

Washington, V., \& Harvey, W. (1989). Affirmative rhetoric, negative action: African American and Hispanic faculty at predominantly white institutions. Washington, DC: George Washington University, School of Education and Human Development. 